\title{
Designing Key Performance Indicators (KPI) with macro ergonomics approach
}

\author{
Abdul Alimul Karim ${ }^{1, *}$, Sri Gunani Partiwi ${ }^{1}$ and Adithya Sudiarno ${ }^{1}$ \\ ${ }^{1}$ Department of Industrial Engineering, Institut Teknologi Sepuluh November, 60111 Surabaya, \\ Indonesia
}

\begin{abstract}
Some Electronic Procurement Agency (LPSE) at the level of Regional Device Work Unit (SKPD) in Indonesia is still in the development stage of its life cycle, so it needs performance improvement. Key Performance Indicator (KPI) is required to measure the performance. To undertake the development of the LPSE, a sociotechnical role is required. Sociotechnical is a concept of macro ergonomics that has a principle of balancing between social and technical in running a system. So this research aims to design KPI with macro Ergonomic approach. This research was conducted at LPSE District of Kampar, Riau, Indonesia. The stages of this research are the selection of Macro Ergonomic Sub-Attributes, Expert Selection with expertise based ranks of expert, weighting using Fuzzy (Analytical Hierarchy Process) AHP, determining the priority of sub macro ergonomic attribute using Pareto and design of KPI. The result of this research are 33 Sub-Attributes of Macro Ergonomic and prioritizing resulted 18 sub-attributes of Macro Ergonomic and result 21 KPI.
\end{abstract}

\section{Preliminary}

The government utilizes information technology to run its government work program which aims to create clean government and good governance. One of them is the development of information technology, which is found in internet network technology known as Electronic Government (E-government). E-government has become an important factor in the change of information systems in each country [1] and the improvement and refinement of performance at all levels of government [2] one of which in Indonesia has started to be regulated in 2001 with regulation no. 6 of 2001 which states that the state apparatus must use telematics technology to support good governance and accelerate the democratic process. One of the government work programs that utilize information technology in the form of procurement of goods or services called the Electronic Procurement Agency (LPSE). The regulation on procurement of goods and services is regulated in Presidential Regulation No. 54/2010 concerning Procurement of Government Goods / Services. One of the objectives of the regulation is to increase accountability. Accountability should be measured in terms of performance accountability based on the state minister's regulation on the utilization of state

\footnotetext{
* Corresponding author: alimulaftakarim@gmail.com
} 
apparatus and bureaucratic reform number 29 of 2010 . To know the level of performance, it is necessary to determine Key performance Indicators (KPI). In addition, referring to Presidential Regulation no. 54 year 2010 announce the procurement plan electronically conducted at the level of Ministry, Institution, Regional Device Unit or Institution (K / L / D / I).

This study focuses on the District Device Work Unit (D) Kampar District because it is in Less Performance Category in 2014 [3] and is in the stage of development of E-procurement. E-procurement has a great influence in the procurement process in the government sector [4], so the development of E-procurement requires the role of sociotechnical [5]. Sociotechnical is the concept of macro ergonomics that seeks to create a harmonious relationship between social and technical [6-8]. The process of developing, of course there are several strategies such as improving human capacity, develop leaders' commitment, develop infrastructure and enhance cooperation [9]. Therefore, to be able to measure the performance of LPSE of Regional Device Work Unit that are developing, then in this research conducted Key Performance Indicators Design with Macro Ergonomics approach as a performance measuring tool in Kampar, Riau, Indonesia.

This paper is divided into several sections. Section 2 discusses the methods and stages used in the study. Section 3 describes the results and discussion of the design of KPI, then closed with conclusions and suggestions.

\section{Methods and Research Stages}

The design of KPI begins at the stage of collecting macro ergonomic sub-attributes and the selection of sub-attributes that are considered important by the expert, Expert Selection, and then assessment by expert and weighting to determine sub-attribute of macro ergonomics which made aspect in the design of KPI.

\subsection{Macro Ergonomics Sub-Attribute Collection}

The collection of macro ergonomic sub-attributes is derived from several references related to macro ergonomics. The subgroup of macro ergonomic subgroup is then screened by 5 experts which is appropriate and important in an e-procurement. The selection process is carried out by distributing a questionnaire of conformity.

\subsection{Expert Selection}

Qualitatively, the selected experts are 5 people based on the highest position. At this stage, the selection of 1 expert has the highest CWS-Index value [10]. Expert selection process is done by spreading pairwise comparison questionnaires to 5 experts, then calculated CWSIndex [10].

$$
\begin{gathered}
p_{i j}=g\left(a_{i j}\right)=\frac{1}{2} x\left(1+\log _{9} a_{i j}\right) \\
\varepsilon p_{i k}^{i 1}=p_{i j}+p_{j k^{-}} \frac{1}{2}, j \neq i, k \\
f(X)=\frac{x+a}{1+2 a}
\end{gathered}
$$

The rate of Discrimination $=\frac{\sum_{j=1}^{n} r(M j-G M)^{2}}{n-1}$

The rate of inconsistent $=\frac{\sum_{j=1}^{n} \sum_{i=j}^{r}(M i j-M j)^{2}}{n(r-1)}$

$$
C W S-\text { Index }=\frac{\text { Discrimination }}{\text { The rate of inconsistent }}
$$




\subsection{Weighting Using Fuzzy AHP}

Weighting is done to get priority macro ergonomic sub-attributes with AHP fuzzy with stages to create AHP structure. The steps taken are to determine the function of fuzzy membership (Table 1) [12], resulting in paired comparisons between attributes and sub-attributes. Determining the fuzzy geometric mean value [11], then determining the fuzzy weight [10] and defuzzyfication with the Center of area (COA) method and normalizing.

$$
\begin{gathered}
\widetilde{r}_{i}=\left(\prod_{j=1}^{n} \tilde{d}_{i j}\right)^{1 / n}, i=1,2, \ldots, n \\
\widetilde{w}_{i}={\widetilde{r_{i}}}_{i} \otimes\left(\widetilde{r}_{l} \otimes \widetilde{r}_{2} \otimes \ldots \otimes \widetilde{r_{n}}\right)^{-1} \\
=\left(l w_{i}, m w_{i}, u w_{i}\right) \\
M_{i}=\frac{\left(l w_{i}, m w_{i}, u w_{i}\right)}{3} \\
N_{i}=\frac{M_{i}}{\sum_{i=1}^{n} M_{i}}
\end{gathered}
$$

Table 1. Function Membership Fuzzy

\begin{tabular}{|l|l|}
\hline \multicolumn{1}{|c|}{ Number of Fuzzy } & \multicolumn{1}{c|}{ Membership Functions } \\
\hline $1^{-}$ & $(1,1,3)$ \\
\hline $\mathrm{x}^{-}$ & $(\mathrm{x}-2, \mathrm{x}, \mathrm{x}+2)$ for $\mathrm{x}=3,5,7$ \\
\hline $9^{-}$ & $(7,9,9)$ \\
\hline
\end{tabular}

\section{Results and Discussion}

Macro Ergonomics Sub attributes applied to the scope of the company [6, 14-15] and the education system [13] with 39 sub attributes. In this research, expert eliminating sub macro

\begin{tabular}{|c|c|c|c|c|c|}
\hline No & Attribute & Sub Attribute & No & Attribute & Sub Attribute \\
\hline \multirow{8}{*}{1} & \multirow{8}{*}{$\begin{array}{c}\text { Organization } \\
{[6,13-15]}\end{array}$} & a. Working Hour & \multirow{5}{*}{4} & \multirow{5}{*}{$\begin{array}{l}\text { Technology } \\
{[6,13-15]}\end{array}$} & r. Capacity \\
\hline & & b. Administration & & & s. Integration \\
\hline & & c. Coordination & & & t. Information Technology \\
\hline & & d. Work Evaluation & & & u. Technology and Tools \\
\hline & & e. Team Work & & & v. System Security \\
\hline & & f. System Dependency & \multirow{6}{*}{5} & \multirow{6}{*}{$\begin{array}{c}\text { Physical } \\
\text { Environment } \\
{[6,13,15]}\end{array}$} & w. Workplace Design \\
\hline & & g. Social Relations & & & x. Lighting \\
\hline & & h. Procedure & & & y. Temperature \\
\hline \multirow{5}{*}{2} & \multirow{5}{*}{$\begin{array}{c}\text { Human } \\
\text { Resources } \\
{[6,13-15]}\end{array}$} & $\begin{array}{l}\text { i. Psychological } \\
\text { Characteristics }\end{array}$ & & & z. Air Quality \\
\hline & & j. Motivation & & & aa. Security \\
\hline & & k. Knowledge & & & ab. Noise \\
\hline & & 1. Skill & & & \\
\hline & & m. Adaptable & \multirow{5}{*}{6} & \multirow{5}{*}{$\begin{array}{l}\text { Information } \\
\text { Systems [14] }\end{array}$} & $\begin{array}{l}\text { ac. Use of Information } \\
\text { Systems }\end{array}$ \\
\hline \multirow{4}{*}{3} & \multirow{4}{*}{$\begin{array}{c}\text { Tasks / } \\
\text { Activities }[6, \\
13,15]\end{array}$} & n. Satisfaction & & & $\begin{array}{l}\text { ad. Implementation } \\
\text { Technology }\end{array}$ \\
\hline & & o. Task Variety & & & ae. Quality of Information \\
\hline & & p. Contents of Work & & & af. Type of Information \\
\hline & & q. Working Controls & & & ag. Database \\
\hline
\end{tabular}
ergonomic attributes that are considered important and influential on LPSE in Government that resulted in 33 sub macro ergonomic attributes. The results of the macro ergonomic subattributes can be seen from Table 2 .

Table 2. Sub-Attributes of Ergonomic Macro Appropriate and Important in an E-Procurement 
Next step is subsequently weighted the macro ergonomic sub-attributes using AHP fuzzy. Then the priority setting is taken based on the Pareto concept. The Pareto concept that states $20 \%$ affects the other $80 \%$. Example on Infrastructure Development [9] (Figure 1).

\section{Infrastructure Development}

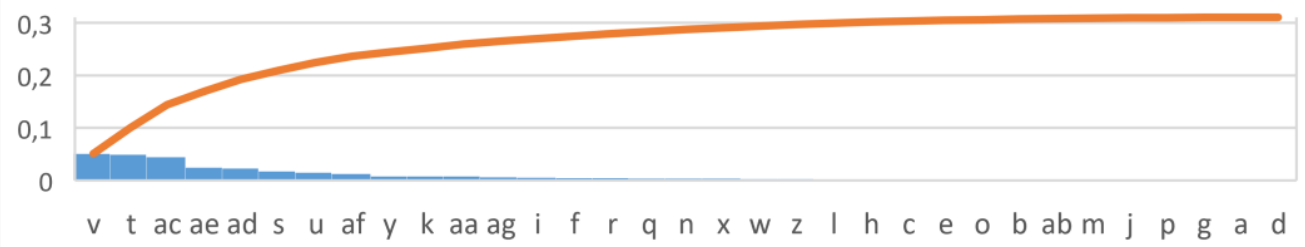

Fig. 1. Pareto Priority Infrastructure Development

In previous studies, formulation of KPI is done with a balanced scorecard approach [16-18], DEMATEL [17] and Performance Prism [19]. In this research, the preparation of Macro Ergonomics KPI approach. Based on the prioritization of each e-procurement development strategy, KPIs are generated in Table 3.

Table 3. Results of KPI Design with Macro Ergonomic Approach

\begin{tabular}{|c|c|c|c|c|}
\hline $\begin{array}{c}\text { Sub-Attribute } \\
\text { Macro } \\
\text { Ergonomics }\end{array}$ & KPI & Formula & $\begin{array}{c}\text { KPI } \\
\text { Characteristics }\end{array}$ & Unit \\
\hline $\begin{array}{l}\text { System } \\
\text { Security (C) }\end{array}$ & $\begin{array}{l}\text { Frequency of e- } \\
\text { procurement service } \\
\text { interruption due to } \\
\text { interference with } \\
\text { system security }\end{array}$ & $\begin{array}{l}\text { The number of disconnected } \\
\text { e-procurement services due to } \\
\text { interference with system } \\
\text { security }\end{array}$ & Lower is better & Multiplication \\
\hline $\begin{array}{l}\text { Information } \\
\text { Technology } \\
\text { (B) }\end{array}$ & $\begin{array}{l}\text { Average time required } \\
\text { to meet user requests }\end{array}$ & $\begin{array}{l}\text { (Number of days to meet user } \\
\text { request / One week) x } 100 \%\end{array}$ & Lower is better & $\%$ \\
\hline $\begin{array}{l}\text { Use of } \\
\text { information } \\
\text { systems }(\mathrm{B}, \mathrm{C})\end{array}$ & $\begin{array}{l}\text { The percentage of } \\
\text { negative comments } \\
\text { received }\end{array}$ & $\begin{array}{l}\text { (Number of negative } \\
\text { comments / entire comments) } \\
\text { x } 100 \%\end{array}$ & Lower is better & $\%$ \\
\hline $\begin{array}{l}\text { Psychological } \\
\text { Characteristics } \\
\text { (A) }\end{array}$ & $\begin{array}{l}\text { Percent of employee } \\
\text { absenteeism }\end{array}$ & $\begin{array}{l}\text { (number of employee } \\
\text { attendance in one month / } \\
\text { total day in one month) } x \\
100 \%\end{array}$ & Lower is better & $\%$ \\
\hline $\begin{array}{l}\text { Knowledge (A, } \\
\mathrm{B}, \mathrm{C}, \mathrm{D})\end{array}$ & $\begin{array}{l}\text { Percentage of training } \\
\text { e-procurement }\end{array}$ & $\begin{array}{l}\text { (number of trainees attended } \\
\text { training / total training held in } \\
\text { one year) } \times 100 \%\end{array}$ & Higher is better & $\%$ \\
\hline $\begin{array}{l}\text { Implementation } \\
\text { of technology } \\
(\mathrm{B}, \mathrm{D})\end{array}$ & $\begin{array}{l}\text { Percentage of users } \\
\text { who make access that } \\
\text { is not in accordance } \\
\text { with its authorization }\end{array}$ & $\begin{array}{l}\text { (number of users accessing } \\
\text { according to authorization / } \\
\text { total e-procurement user) } x \\
100 \%\end{array}$ & Higher is better & $\%$ \\
\hline $\begin{array}{l}\text { Implementation } \\
\text { of technology } \\
\text { (D) }\end{array}$ & $\begin{array}{l}\text { The number of } \\
\text { percentage disruption } \\
\text { to the system that } \\
\text { occurred in a certain } \\
\text { period }\end{array}$ & $\begin{array}{l}\text { (number of days of disruption } \\
\text { to implementation / total day } \\
\text { of implementation) x } 100 \%\end{array}$ & Higher is better & $\%$ \\
\hline $\begin{array}{l}\text { Quality of } \\
\text { Information } \\
\text { (D) }\end{array}$ & $\begin{array}{l}\text { Percentage of data } \\
\text { completeness of goods } \\
\text { and service providers }\end{array}$ & $\begin{array}{l}\text { (The amount of filtered data / } \\
\text { whole data that should be } \\
\text { present) } \times 100 \%\end{array}$ & Higher is better & $\%$ \\
\hline $\begin{array}{l}\text { Satisfaction } \\
\text { (D) }\end{array}$ & $\begin{array}{l}\text { Index of user } \\
\text { satisfaction results } \\
\text { about IT users from } \\
\text { internal government }\end{array}$ & $\begin{array}{l}\text { User satisfaction survey } \\
\text { results }\end{array}$ & Higher is better & Likert Scale \\
\hline
\end{tabular}




\begin{tabular}{|c|c|c|c|c|}
\hline $\begin{array}{l}\text { Sub-Attribute } \\
\text { Macro } \\
\text { Ergonomics } \\
\end{array}$ & KPI & Formula & $\begin{array}{c}\text { KPI } \\
\text { Characteristics }\end{array}$ & Unit \\
\hline & $\begin{array}{l}\text { Index of user } \\
\text { satisfaction results } \\
\text { about IT users from } \\
\text { external government } \\
\end{array}$ & $\begin{array}{l}\text { User satisfaction survey } \\
\text { results }\end{array}$ & Higher is better & Likert Scale \\
\hline $\begin{array}{l}\text { Technology } \\
\text { and Supporting } \\
\text { Tools (A) }\end{array}$ & $\begin{array}{l}\text { Index Development } \\
\text { technology and support } \\
\text { tools }\end{array}$ & $\begin{array}{l}\text { (The share of technology } \\
\text { development costs and } \\
\text { supporting tools / total local } \\
\text { government budget) x } 100 \%\end{array}$ & Higher is better & $\%$ \\
\hline $\begin{array}{l}\text { Skill (A, B, C, } \\
\text { D) }\end{array}$ & $\begin{array}{l}\text { Percentage of time in } \\
\text { completing work }\end{array}$ & $\begin{array}{l}\text { (time in completing the job / } \\
\text { time portion of completing } \\
\text { the work that has been } \\
\text { determined) } \times 100 \%\end{array}$ & Higher is better & $\%$ \\
\hline $\begin{array}{l}\text { Integration }(\mathrm{B}, \\
\mathrm{C})\end{array}$ & $\begin{array}{l}\text { Percentage of } \\
\text { integrated updating } \\
\text { process }\end{array}$ & $\begin{array}{l}\text { (The number of successful } \\
\text { updating processes / total } \\
\text { updating process) } \times 100 \%\end{array}$ & Stabilize is best & $\%$ \\
\hline Team work (B) & $\begin{array}{l}\text { The percentage of the } \\
\text { process of providing } \\
\text { unserved goods or } \\
\text { services }\end{array}$ & $\begin{array}{l}\text { (Number of processes of } \\
\text { providing unserved goods or } \\
\text { services / total process of } \\
\text { providing goods or services) } \\
\text { x } 100 \%\end{array}$ & Higher is better & $\%$ \\
\hline Capacity (C) & $\begin{array}{l}\text { Amount of Data } \\
\text { Capacity available }\end{array}$ & $\begin{array}{l}\text { (Total data capacity filled / } \\
\text { total data available) x } 100 \%\end{array}$ & Higher is better & $\%$ \\
\hline $\begin{array}{l}\text { Adaptable }(\mathrm{B}, \\
\mathrm{C}, \mathrm{D})\end{array}$ & $\begin{array}{l}\text { Percentage of } \\
\text { employee adaptation } \\
\text { time at system update }\end{array}$ & $\begin{array}{l}\text { (Number of employees who } \\
\text { successfully adapt to the new } \\
\text { system / total Employees } \\
\text { who must adapt to the new } \\
\text { system) x } 100 \%\end{array}$ & Stabilize is best & $\%$ \\
\hline Procedure (D) & $\begin{array}{l}\text { Percentage of process } \\
\text { of providing goods or } \\
\text { services in accordance } \\
\text { with procedures }\end{array}$ & $\begin{array}{l}\text { (The number of processes for } \\
\text { the supply of goods or } \\
\text { services that are not in } \\
\text { accordance with the } \\
\text { procedure / total process of } \\
\text { providing goods or services) } \\
\text { x } 100 \%\end{array}$ & Lower is better & $\%$ \\
\hline $\begin{array}{l}\text { Type of } \\
\text { information }(B, \\
\text { C) }\end{array}$ & $\begin{array}{l}\text { The large number of } \\
\text { types of information } \\
\text { that facilitate e- } \\
\text { procurement users }\end{array}$ & $\begin{array}{l}\text { Number of types of } \\
\text { information the user needs }\end{array}$ & Higher is better & Multiplication \\
\hline \multirow{2}{*}{$\begin{array}{l}\text { Working } \\
\text { Controls (D) }\end{array}$} & $\begin{array}{l}\text { Rating given from the } \\
\text { audit process of the } \\
\text { external auditor over a } \\
\text { period of time }\end{array}$ & $\begin{array}{l}\text { (the number of unmet } \\
\text { standards / } 9 \text { standards LPSE) } \\
\text { x } 100 \%\end{array}$ & Higher is better & $\%$ \\
\hline & $\begin{array}{l}\text { Rating given from the } \\
\text { audit process of the } \\
\text { internal auditor over a } \\
\text { certain period of time }\end{array}$ & $\begin{array}{l}\text { (standard number not met / } 17 \\
\text { standard LPSE) x } 100 \%\end{array}$ & Higher is better & $\%$ \\
\hline $\begin{array}{l}\text { Server Room } \\
\text { Temperature } \\
\text { (D) }\end{array}$ & $\begin{array}{l}\text { Server Room } \\
\text { Temperature }\end{array}$ & $\begin{array}{l}18^{0} \mathrm{C}<\text { Room Temperature }< \\
27^{0} \mathrm{C}\end{array}$ & Stabilize is best & ${ }^{0} \mathrm{C}$ \\
\hline
\end{tabular}

Information: $\mathrm{A}=$ Head of Subdivision LPSE, $\mathrm{B}=$ Sub Division of Information Technology Information Team, $\mathrm{C}=$ Sub Division of Program, $\mathrm{D}=$ Sub Division of Evaluation, Control and Reporting

\section{Conclusion}

The result of this research is that there are 33 sub-attributes of ergonomic macro appropriate and important in an e-procurement. Each macro ergonomic attribute contributes to the design 
of KPIs in the LPSE Regional Device Work Unit consisting of 18 sub-attributes of macro ergonomics. This is consistent with Hardy and William's statement [5]. Although the design of KPI is dominated by macro ergonomic attributes of technology, information systems and human resources, but the organizational attributes, tasks / activities and physical environment still contribute even if there is only one or few sub-attributes. Eighteen sub-attributes of ergonomic macro formed $21 \mathrm{KPI}$ divided by tasks on each parts of the work that existed in the LPSE Regional Device Work Unit. The suggestion for the next research is to develop Key Risk Indicators (KRI) to strengthen the assessment of the already designed KPIs. This research is conducted at the Regional Device Work Unit, if it can be done at the level of Ministry, Institution and Institution in accordance with Presidential Regulation no. 54 year 2010 to be able to see how big the effect of macro ergonomic on LPSE performance. And perform sensitivity analysis on AHP fuzzy weighting results.

Our thanks go to the district administration of Kampar which is willing to be the object of our research, and to Purwoko as a companion when doing research in the district of Kampar and to Riki Pratama, Nurbit, Wira Herman, Malvinas and Sukirman as expert respondents.

\section{References}

1. J. Taylor, M. Lips, J. Organ, Public Money and Management, 27, 161-164. (2007)

2. T. F. Gordon, ERCIM News. 48. 12 - 13. (2002)

3. T. F. Gafar, JDP, 1, 50-73. (2018)

4. D. Neef, E-Procurement: From strategy to implementation. FT press. 109 (2001)

5. C. A. Hardy, S. P. Williams, Government Information Quarterly, 25, 155-180. (2008)

6. H. W. Hendrick, B. M. Kleiner, (Eds.). Macroergonomics: theory, methods, and applications. 3. (2002)

7. C. H. Davis, F. B. Moro, Twelfth International Conference on Management of Technology, Washington. (2004)

8. A. Cherns, Human relations, 29, 783-792. (1976)

9. Y. G. Sucahyo, Y. Ruldeviyani, LKPP, (2009)

10. E. Herowati, U. Ciptomulyono, J. Parung, Suparno, Fuzzy Sets and Systems, 315, 4456. (2017).

11. J. J. Buckley, Fuzzy sets and systems, 17, 233-247. (1985).

12. H. Deng, International journal of approximate reasoning, 21, 215-231. (1999)

13. J. D. Silva, S. G. Partiwi, U. Ciptomulyono, Prosiding Seminar Nasional Management teknologi. (2016)

14. J. Kantola, W. Karwowski, Proceedings of the Human Factors and Ergonomics Society Annual Meeting. 44. (2000)

15. A. R. Vargas, J. L. G. Alcaraz, J. B. Fernández, Contaduría y administración, 61. 478498. (2016)

16. K. Vaidya, G. Callender, A. S. M. Sajeev, J. Gao. Australian e-Governance Conference, (2004)

17. H. Rahimi, J. Bahmaei, P. Shojaei, Z. Kavosi, M. Khavasi, Journal Demo Neoscriber V3 single, (2018)

18. S. Rotchanakitumnuai, International Journal of Physical Distribution \& Logistics Management, (2013)

19. N. U. Handayani, H. Santoso, \& S. Rochmawati, Jurnal Teknoin, 10.4 (2005) 